\title{
Sowing speed in no tillage system on early development of maize crop
}

Velocidade operacional em sistema de semeadura direta no desenvolvimento inicial da cultura do milho

\author{
M. V. Paulo ${ }^{1}$; R. C. Tieppo ${ }^{1 *}$; A. J. Modolo ${ }^{2}$; R. Dallacort ${ }^{1}$; A. Santi ${ }^{1}$ \\ ${ }^{I}$ Department of Agricultural Engineering- CETEGEO, UNEMAT, 78300-000, Tangará da Serra-MT, Brazil \\ ${ }^{2}$ Department of Agricultural Engineering, UTFPR, 85503-390, Pato Branco-PR, Brazil
}

*rafaelt@unemat.br

(Recebido em 24 de setembro de 2017; aceito em 15 de fevereiro de 2018)

\begin{abstract}
Sowing is a fundamental stage in crops' cultivation process. If performed improperly, it can compromise the entire crop development. Seeding speed stands out as a key factor which can affect seeding quality. The objective of this study was to assess the effects of variation of working speed in maize initial establishment and in direct seeding's' quality parameters. The experiment was carried out in the municipality of Tangará da Serra - MT. Four seeding speeds were used V1 equal 1.11 (4.0), V2 equal 1.39 (5.0), V3 equal 1.67 (6.0) and V4 equal $1.94 \mathrm{~m} \mathrm{~s}^{-1}\left(7.0 \mathrm{~km} \mathrm{~h}^{-1}\right)$. The assessed parameters were emergence speed index, emergence rate, seed deposition depth, plant spacing, and initial plant population. No interference of seeding speed variation was observed in seed deposition depth, emergence speed index and initial plant population. However, seeding speed influenced in plant spacing, in which speed increase was proportional to plant spacing increase.

Keywords: seedling emergence. longitudinal distribution. seed deposition depth
\end{abstract}

A semeadura é uma das etapas fundamentais no processo de cultivo, haja visto, que se realizada de forma inadequada pode comprometer todo o desenvolvimento da cultura. Neste processo a velocidade de semeadura destaca-se como fator primordial que pode prejudicar a qualidade de semeadura. Portanto, objetivou-se neste trabalho verificar o efeito da variação de velocidade de trabalho no estabelecimento inicial da cultura do milho e nos parâmetros de qualidade da semeadura direta do milho. O experimento foi realizado no município de Tangará da Serra - MT. Utilizou-se quatro velocidades de semeadura sendo: V1 igual a 1.11 (4.0), V2 igual a $1.39(5.0)$, V3 igual a $1.67(6.0)$ e V4 igual a $1.94 \mathrm{~m} \mathrm{~s}^{-1}\left(7.0 \mathrm{~km} \mathrm{~h}^{-1}\right)$. Foram analisadas as variáveis índice de velocidade de emergência, marcha de emergência, profundidade de deposição das sementes, espaçamento entre plantas, e a população inicial de plantas. Não foi observado a interferência da variação de velocidade nas variáveis profundidade de deposição de sementes, e índice de velocidade de emergência. Entretanto, a velocidade influenciou na variável espaçamento entre plantas, em que o incremento de velocidade foi proporcional ao aumento nos espaçamentos entre plantas.

Palavras-chave: emergência de plântulas, distribuição longitudinal, profundidade de deposição de sementes

\section{INTRODUCTION}

Maize (Zea mays) is considered one of the main grain crops, both in Brazil and abroad. The state of Mato Grosso stands out as the largest grain producer. The prospect for 2016/2017 growing season is about 23 million tons of total production. This value represents an increase of $52 \%$ when it is compared with previous growing season [5].

Accordingly, all processes intrinsic to the production cycle, from sowing to harvest, must be cautiously carried out in order to obtain excellence in cultivation and profitable yield at the end of the cycle.

Sowing operation is one of the fundamental steps in the cultivation process; if it performed incorrectly it can compromise seed deposition depth in the soil, speed of emergence, uniformity in seed distribution, and consequently the final stand of plants [1]. Sowing can be considered as a stage in maize cultivation that requires great perfection in the execution since it can compromise 
the use of natural resources such as light, water, and nutrients, as well as the profitability of agricultural activity [15].

According to [18], several factors can affect sowing, such as soil and climate conditions, straw management, and furrowing mechanisms. However, the authors highlight the seeding speed as a prime factor in the quality of the process. The objective of this study was to evaluate seeding quality parameters and initial establishment of maize when submitted to seeding speed variation in a notill system.

\section{MATERIAL AND METHODS}

The work was carried out at São José farm, located in the municipality of Tangará da Serra county - Mato Grosso State (14,62 S; 57,47 W), altitude of 456 meters, with average annual rainfall of $1500 \mathrm{~mm}$, average annual temperature of $24.4{ }^{\circ} \mathrm{C}$ [6]. The soil was classified as a clayey dystroferric Red Latosol [7].

A New Holland tractor model T7 245 was employed, with front-wheel assist, and maximum power of $223 \mathrm{hp}(164 \mathrm{~kW})$. A Case IH brand planter, model ASM 1224, with 24 rows and double disc coulter for fertilizer and seeds, and V-shaped compacting wheel. The seed metering mechanism used was a horizontal perforated disc, with 48 holes.

Sowing was performed on 03/17/2017 with a maize hybrid MG 652, with Power Core TM technology which confers lepidopteran resistance and tolerance to glyphosate and glufosinate ammonium herbicides. Row spacing was $0.45 \mathrm{~m}$ with seeds distribution on $2.7 \mathrm{~m}^{-1}$, corresponding to a planned density of 60000 plants ha ${ }^{-1}$.

The experimental design was a randomized blocks, consisting of four treatments with four replications, totaling 16 plots. Each plot had an area of $324 \mathrm{~m}^{2}(30 \times 10.8 \mathrm{~m})$. Samples evaluated variables were collected from eight central lines within each plot, discarding $0.5 \mathrm{~m}$ at start and final.

Treatments were represented by four theoretical sowing speeds, V1equal $1.11 \mathrm{~m} \mathrm{~s}^{-1}\left(4.0 \mathrm{~km} \mathrm{~h}^{-}\right.$ $\left.{ }^{1}\right)$, V2 equal $1.39 \mathrm{~m} \mathrm{~s}^{-1}\left(5.0 \mathrm{~km} \mathrm{~h}^{-1}\right), \mathrm{V} 3$ equal $1.67 \mathrm{~m} \mathrm{~s}^{-1}\left(6.0 \mathrm{~km} \mathrm{~h}^{-1}\right)$ and V4 equal $1.94 \mathrm{~m} \mathrm{~s}^{-1}(7.0$ $\mathrm{km} \mathrm{h}^{-1}$ ). These velocities were determined based on the average speed values obtained in the field. A distance of 10 meters, before each plot, was used to allow the establishment of speed of work on each treatment.

Soil physical conditions in the experimental area were carried out in each plot before sowing to verify soil density, moisture, and cover. Soil density and moisture assessment was performed according to the methodology proposed by [8]. Soil cover was determined by randomly collecting the biomass within a quadrat frame $\left(1.0 \mathrm{~m}^{2}\right)$. Subsequently, the samples were weighed, and conditioned in a forced air circulation oven for $72 \mathrm{~h}$ at $65^{\circ} \mathrm{C}$. After, dried samples were weighted, and the soil cover was obtained by mean the difference between the wet and dry mass of the biomass, extrapolating it for tonnes per hectare.

Soil density and soil cover values were homogeneous (F-test 5.0\%) for all blocks. The soil density values were $1.37,1.33,1.19$, and $1.36 \mathrm{~g} \mathrm{~cm}^{-3}$, and soil cover values were $3.67,3.57,3.28$, and $3.78 \mathrm{t} \mathrm{ha}^{-1}$, for blocks B1, B2, B3, and B4, respectively.

About soil moisture characteristic, the values for bocks B1, B2, B3 and B4 were 20.81, 19.82, 18.76, and $18.48 \%$. We noticed that the moisture in Block 1 was different from the others (F-test and Tukey test $5.0 \%$ ). It was because of the difference among sampling time. The moisture samples were collected around 10 minutes before sowing procedure. How for the Block 1, the sowing was accomplished at 8:00 am, and for the last one block (Block 4) it was finished around 3:00 pm, in this period the soil moisture was decreasing by weather factors (solar radiation, wind). Taking into the need for homogeneous features among the blocks, all data from block 1 were dropped.

Three variables were evaluated: emergence speed index, seed deposition depth and plant spacing. For each of them were made six, ten, and ten measures per plot, respectively. From those measures, the average for each plot was calculates to express the treatment effect. Data were submitted to analysis of variance ( $F$ test), and regression analysis, both of them at a 5.0\% probability level, using by means of R statistical software [14]. 
The emergence speed index (IVE) was assessed according to [12], whom propose daily counts of seedlings until it becomes constant. This procedure was carried out in a random line within the work area of the plots, with $25.0 \mathrm{~m}$ of length. The IVE will be expressed by equation 1 .

$$
I V E=\frac{E_{1}}{N_{1}}+\frac{E_{2}}{N_{2}}+\ldots+\frac{E_{n}}{N_{n}}(\text { eq. } 01)
$$

where: IVE: Emergency speed index; E1, E2, En: number of emerged seedlings in the first, second, and nth counts; $\mathrm{N}_{1}, \mathrm{~N}_{2}, \mathrm{~N}_{\mathrm{n}}$ : number of days after sowing to the first, second, and nth counts.

In relation to emergence, it was considered as emerged seedlings, the moment they have broken the ground and that can be seen with the naked eye, from any angle and constant. The existence of stabilization of the emergency was assigned when the number of emerged plants was constant during three consecutive evaluations. The emergence rate was determined by the percentage of plants emerged as a function of days after sowing (DAS).

Seed depth deposition was determined soon after planting by removing the soil over them. Ten samplings were carried out in two random sowing lines, with five seeds per each row. To measure the depth, a centimeter graduated ruler was used.

The spacing between plants was evaluated after the stabilization of the emergency, by a measuring tape placed on the soil. The measurements were randomly made in two sowing lines within the work area of each plot, with five samples in each row, totalizing ten samples per plot. The initial population of plants was determined from the average spacing between plants.

\section{RESULTS AND DISCUSSION}

Average speed for V1, V2, V3, and V4 treatments were 1.1, 1.4, 1.7, and $2.02 \mathrm{~m} \mathrm{~s}^{-1}$ (4.2, 5.1, 6.2 , and $7.3 \mathrm{~km} \mathrm{~h}^{-1}$ ) respectively, and standard deviation were $0.1,0.6,0.1$, and 0.1 respectively, showing low variations among the measurements. The variance analysis indicates the effect of speed factor in the evaluated variables (Tables 1, 2 and 3).

Table 1: Summary of the Analysis of variance of deposition depth

\begin{tabular}{ccrrrl}
\hline Source of variation & Df & Sum Sq & Mean Sq & F value & $\operatorname{Pr}(>\mathrm{F})$ \\
\hline Speed & 1 & 0.0130721 & 0.0130721 & $0.121436^{\text {ns }}$ & 0.76 \\
\hline Residuals & 2 & 0.2152918 & 0.1076459 & & \\
\hline
\end{tabular}

${ }^{*} \mathrm{p}<0.05 ;{ }^{\mathrm{ns}}$ Non significant $(\mathrm{p} \geq 0.05)$.

Table 2 Summary of the Analysis of variance of IVE

\begin{tabular}{cccccc}
\hline Source of variation & Df & Sum Sq & Mean Sq & F value & $\operatorname{Pr}(>\mathrm{F})$ \\
\hline Speed & 1 & 9.976877 & 9.9768766 & $12.74724^{\mathrm{ns}}$ & 0.07 \\
\hline Residuals & 2 & 1.565340 & 0.7826698 & & \\
\hline
\end{tabular}

$* \mathrm{p}<0.05 ;{ }^{n s}$ Non significant $(\mathrm{p} \geq 0.05)$.

Table 3 Summary of the Analysis of variance of plant spacing

\begin{tabular}{cccccc}
\hline Source of variation & Df & Sum Sq & Mean Sq & F value & $\operatorname{Pr}(>\mathrm{F})$ \\
\hline Speed & 1 & 0.0041889 & 0.0041889 & $56.17661^{*}$ & 0.02 \\
\hline Residuals & 2 & 0.0001491 & 0.0000746 & & \\
\hline
\end{tabular}

$*_{\mathrm{p}}<0.05 ;{ }^{\mathrm{ns}}$ Non significant $(\mathrm{p} \geq 0.05)$. 
Regarding the speed range, there was not effect from speed in seed deposition depth, and IVE, as well (Tables 1, and 2). Therefore, for those soil conditions, we can assert that the planter can work in speed range evaluated without provide harms in seed deposition depth, and IVE. Perhaps, for higher speeds, the planter may provide a no satisfactory performance for deposition depth. Observing seed deposition depth averages $(0.04,0.03,0.04$, and $0.04 \mathrm{~m})$, and standard deviations $(0.004,0.006,0.006$, and 0.008$)$, for $\mathrm{V} 1, \mathrm{~V} 2, \mathrm{~V} 3$, and V4 respectively, we can detect a trend to increase the variation around the average of the seed deposition depth (Figure 1a). About IVE variable, it is possible to note that same increasing the speed, there is no standard deviation rise (Figure 1b).
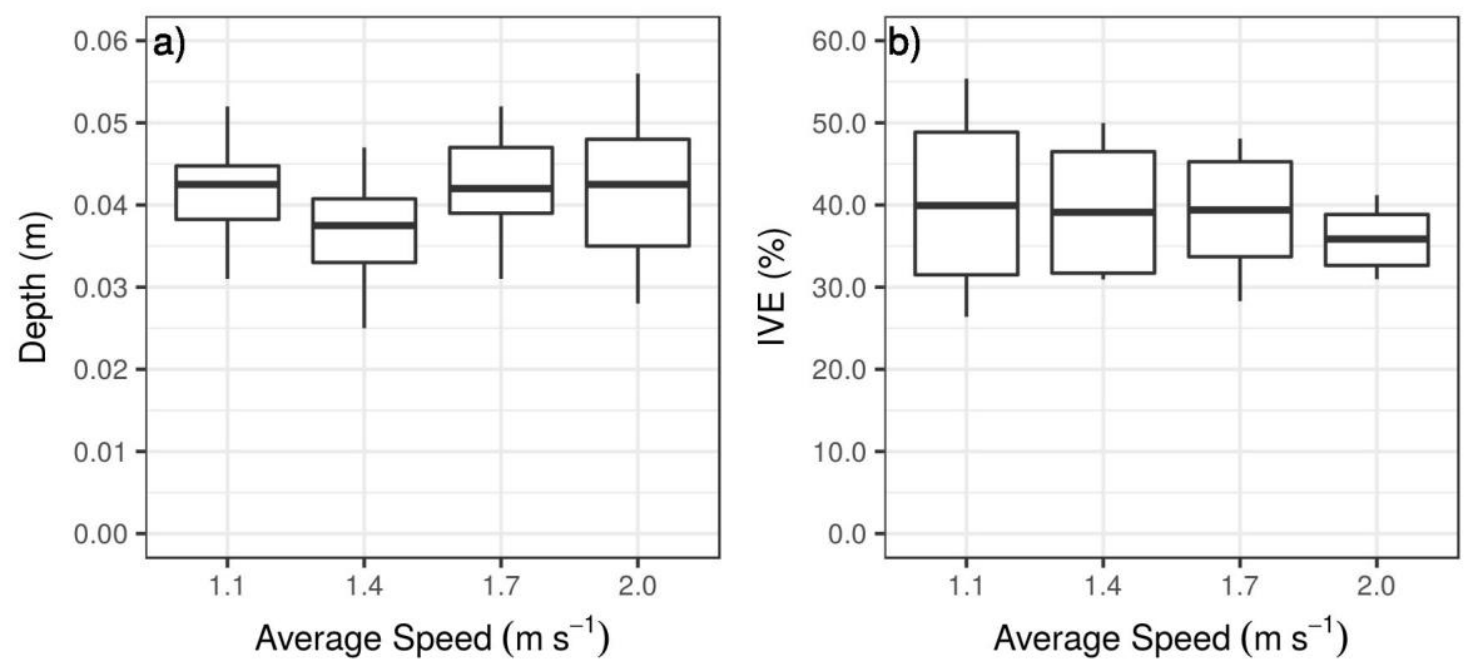

Figure 1 - Boxplot for depth deposition (a) and IVE (b)

Sowing depth values were within the expected range, between 3 and $5 \mathrm{~cm}$ [9]. Similar results were obtained by [18] in which the increase in speed also did not influence the depth of deposition of maize seeds.

These results may be related to the uniformity of seed deposition depth obtained in this experiment, which provided similar conditions for the emergence process of the seedlings. [17] evaluated seeding speeds on 4.5 and $7.0 \mathrm{~km} \mathrm{~h}^{-1}$. These authors obtained similar results, in which there was no significant difference for IVE as a function of sowing speed variation.

For all treatments, seedlings emerged at 5 DAS, with variation only in the stabilization period of the emergency (Figure 2).

It can be observed that the seedlings started the emergence on the fifth DAS in all treatments. In the period between the sixth and the tenth DAS there was an increase in the emergence of seedlings, occurring variation in the stabilization period of the emergency for each seeding speed. On the fifth DAS, it was verified that $66.8,69.1,64.7$, and $63.7 \%$ of seeds emergence occurred at V1, V2, V3, and V4, respectively. This result could validate the uniformity of seedling emergence speed when related to the assessed speeds. The emergence speed is a very important characteristic for crop establishment, since the shorter the period in which the seeds are in contact with soil, the less they are susceptible to attack by pathogens and insects [11]

The variable plant spacing $(\mathrm{p}=0.02)$ showed significant difference at the $5 \%$ level. Mean values achieved were $0.36,0.38,0.40$, and $0.45 \mathrm{~m}$ as a function of speeds 1.1 (4.2), $1.4(5.0), 1.7$ (6.2), and $2.0 \mathrm{~m} \mathrm{~s}^{-1}\left(7.3 \mathrm{~km} \mathrm{~h}^{-1}\right)$, respectively. Regression model fitted for plant spacing was linear, which both angular coefficient and intercept are significant. It was observed that with the increase in seeding speed, there was an increase in spacing between plants (Figure 3). 


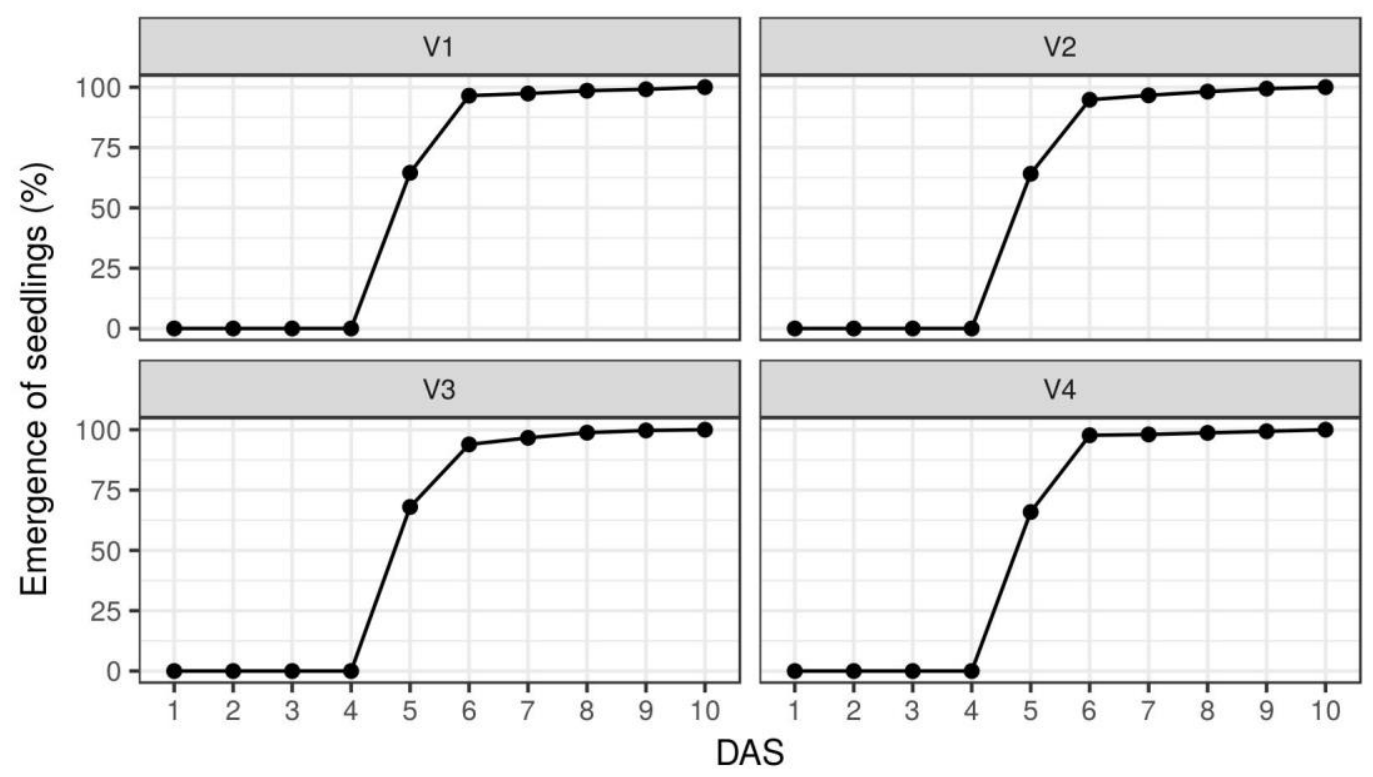

Figure 2 - Maize seedling emergency rate as a function of seeding speeds of $1.11 \mathrm{~m} \mathrm{~s}^{-1}$ (VI), $1.39 \mathrm{~m} \mathrm{~s}^{-1}$ (V2), $1.67 \mathrm{~m} \mathrm{~s}^{-1}(\mathrm{~V} 3)$, and $1.94 \mathrm{~m} \mathrm{~s}^{-1}$ (V4).

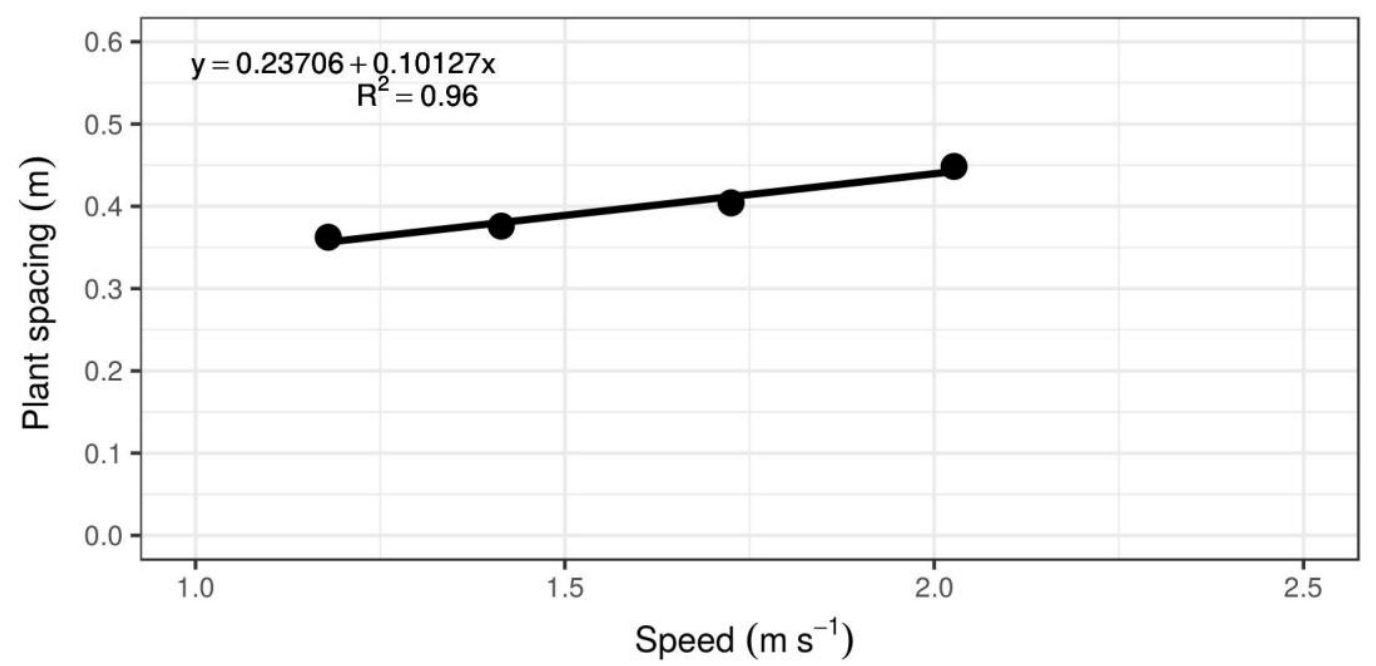

Figure 3 - Spacing between plants as a function of maize sowing speed.

Considering a population of 60.000 plants ha $^{-1}$, plant spacing should be $0.37 \mathrm{~m}$. According to the equation, this value would be reached at a speed of $1.3 \mathrm{~m} \mathrm{~s}^{-1}$. Similar to this study, [17] verified a relationship between the increase of seeding speed and larger spacing between plants. This was also verified by [18] in which they observed the variation in seed distribution as a function of seeding speeds.

Due to a smaller spacing than the desired one, there was an increase in plant population at the speed of $1.1 \mathrm{~m} \mathrm{~s}^{-1}$, resulting in 61480 plants ha $^{-1}$. Speeds of 1.7 and $2.0 \mathrm{~m} \mathrm{~s}^{-1}$ resulted in relatively lower plant populations, of 55,391 and 49,744 plants ha ${ }^{-1}$, respectively.

Similar to the current results, [10] observed that the increase in seeding speed reduced the number of deposited ones per meter, resulting in the reduction of plants per hectare. For [2], it was observed a decrease in the population of plants per hectare as the speed increased, due to the decrease of plants per meter.

The use of high speeds compromised sowing quality, since as speed increased, the proportional increase rotation of seed discs reduced the seed discs filling time, resulting in irregular plant spacing [4]. The regularity of spacing between plants is essential for an effective resources use, e.g., sunlight, water, nutrients necessary for proper crop development and the achievement of satisfactory yields [3] [13] [16]. 
The uniformity in the longitudinal distribution of seeds is a desirable characteristic, since its irregularity directly influences on crop development through double and faulted spacing appearance. This contributes to intraspecific resources competition, as well as the emergence of invasive plants which damages the establishment of the crop.

\section{CONCLUSION}

It was observed that the speed variation had no influence on the initial performance of the crop regarding the rate of emergence speed, the initial population of plants and the depth seed deposition quality parameter. The seeding speed interfered in the spacing between plants, resulting in larger spacing. Considering the desired spacing between plants, the optimum speed was around $1.3 \mathrm{~m} \mathrm{~s}^{-1}$.

\section{REFERENCES}

1. Almeida RAS, Silva CAT, Silva SL. Desempenho energético de um conjunto trator semeadora em função do escalonamento de marchas e rotações do motor. Agrarian. 2010;3:63-70.

2. Bitencourt R, Tavares CA, Foralosso AA, Vigano JP, Oliveira LG, Duarth M, et al. Influência da velocidade de deslocamento da semeadora, com haste sulcadoras na produtividade do milho. Rev Cultiv o Saber. 2008;1:24-33.

3. Bottega EL, Rosolem DH, Neto AMO, Piazzetta HL, Guerra N. Qualidade de semeadura do milho em função do sistema dosador de sementes e velocidades de operação. Sci Technol. 2014;7:107-14.

4. Canova R, Silva RP, Furlani CE, Cortez JW. Distribuição de sementes por uma semeadora-adubadora em função de alterações mecanismo dosador e de diferentes velocidades de deslocamento. Eng na Agric. 2007;15:299-306.

5. CONAB. Acompanhamento da safra brasileira: Milho 1a e 2a Safra - Brasil [Internet]. Brasília,; 2015. Available from: http://www.conab.gov.br/

6. Dallacort R, Martins JA, Inoue MH, Freitas PSL, Coletti AJ. Distribuição das chuvas no município de Tangará da Serra, médio norte do Estado de Mato Grosso, Brazil. Acta Sci Agron. 2011;33:193-200.

7. EMBRAPA EB de PA. Sistema Brasileiro de Classificação de solos. 2nd ed. Rio de Janeiro: Centro Nacional de Pesquisa de Solos; 2006. 306 p.

8. EMBRAPA EB de PA. Manual de métodos de análise de solo. 2nd ed. Rio de Janeiro: Centro Nacional de Pesquisa de Solos; 1997. 212 p.

9. Fancelli AL, Dourado Neto D. Produção de milho. Guaíba: Agripecuária; 200AD. 360 p.

10.Garcia RF, Vale WG do, Oliveira MTR de, Pereira ÉM, Amim RT, Braga TC. Influência da velocidade de deslocamento no desempenho de uma semeadora-adubadora de precisão no Norte Fluminense. Acta Sci Agron [Internet]. 2011 Jun 22;33(3), doi:10.4025/actasciagron.v33i3.6085

11. Modolo AJ, Trogello E, Nunes AL, Silveira JCM da, Kolling EM. Efeito da compactação do solo sobre a semente no desenvolvimento da cultura do feijão. Acta Sci Agron [Internet]. 2011 Mar;33(1), doi: 10.4025/actasciagron.v33i1.4236

12.Nakagawa J. Testes de vigor baseados na avaliação das plântulas. In: Testes de vigor em sementes. Jaboticabal: FUNEP; 1994. p. 49-86.

13.Pinheiro Neto R, Braccini ADL e, Scapim CA, Bortolotto VC, Pinheiro AC. Desempenho de mecanismos dosadores de sementes em diferentes velocidades e condições de cobertura do solo. Acta Sci Agron [Internet]. 2008 Dec;30(5), doi:10.4025/actasciagron.v30i5.5960

14.R Core Team. R: A Language and Environment for Statistical Computing [Internet]. Vienna, Austria; 2017. Available from: http://www.r-project.org/

15.Ros V de V, Souza CMA de, Vitorino ACT, Rafull LZL. Oxisol resistence to penetration in no-till system after sowing. Eng Agrícola [Internet]. 2011 Dec;31(6):1104-14, doi:10.1590/S010069162011000600008

16.Sangoi L, Schmitt A, Vieira J, Picoli Junior J, Souza CA, Casa RT, et al. Variabilidade na distribuição espacial de plantas na linha e rendimento de grãos de milho. Rev Bras Milho e Sorgo. 2012;11:268-77.

17.Storck L, Modolo AJ, Brum B, Trogello E, Franchin MF, Adami PF. Medida de regularidade do espaçamento de plantas de milho em diferentes sistemas de manejo. Rev Bras Eng Agrícola e Ambient [Internet]. 2015 Jan;19(1):39-44. DOI: 10.1590/1807-1929/agriambi.v19n1p39-44 
18.Trogello E, Modolo AJ, Scarsi M, Silva CL da, Adami PF, Dallacort R. Manejos de cobertura vegetal e velocidades de operação em condições de semeadura e produtividade de milho. Rev Bras Eng Agrícola e Ambient [Internet]. 2013 Jul;17(7):796-802, doi:10.1590/S1415-43662013000700015 